International Journal on Design and Manufacturing Technologies, Vol.4, No.2, July 2010

\title{
FABRICATION METHODS, MECHANICAL PROPERTIES, AND INDUSTRIAL APPLICATIONS OF METAL MATRIX COMPOSITE MATERIALS
}

\author{
Thoguluva Raghavan Vijayaram \\ Faculty of Manufacturing Engineering, Universiti Teknikal Malaysia Melaka, Malaysia \\ E-mail: vijayaram1@gmail.com
}

\begin{abstract}
Metal matrix composite materials are composed of an element or an alloy matrix in which a second phase is embedded and distributed to achieve some property improvement. Based on the size, shape and amount of the second phase, the composite property varies. It has outstanding benefits due to the combined metallic and ceramic properties, thereby yielding improved physical and mechanical properties. Actually, it represent a new generation of engineering materials in which a strong ceramic reinforcement is incorporated into a metal matrix to improve its properties including specific strength, specific stiffness, wear resistance, corrosion resistance and elastic modulus. It combine the metallic properties of matrix alloys such as ductility and toughness with ceramic properties of reinforcements like high strength and high modulus, leads to greater strength in shear and compression and higher service-temperature capabilities. Thus, they have significant scientific, technological and commercial importance. In this paper, fabrication methods, mechanical properties, and industrial applications of different types of metal matrix composites are discussed in a comprehensive manner.
\end{abstract}

Keywords: Metal matrix composites, ceramic particulate composites, discontinuous fibre reinforced composites, mechanical properties, industrial applications

\section{INTRODUCTION}

Metal matrix composites are materials that are attractive for a large range of engineering applications. They are a family of new materials, which are attracting considerable industrial interest and investment worldwide. The microstructure of the processed composites influences and has a great effect on the mechanical properties. Generally, increasing the weight fraction of the reinforcement phase in the matrix leads to an increased stiffness, yield strength and ultimate tensile strength. However, the low ductility of particulate reinforced MMCs is the major drawback that prevents their usage as structural components in some applications[1]. Metal matrix composites are composites with a metal or alloy matrix. It has higher elastic modulus, resistance to elevated temperatures, higher toughness and ductility. The limitations are higher density and greater difficulty in processing parts. Because of their high specific stiffness, lightweight, and high thermal conductivity, boron fibres in an aluminium matrix have been used for structural tubular supports in the space shuttle orbiter. MMCs having silicon carbide fibres and a titanium matrix are being used for the skin, beams, stiffeners and frames of the hypersonic aircraft under development. Other applications are in bicycle frames and sporting goods. Composite materials are continuously displacing traditional engineering materials because of their advantages of high stiffness and strength over homogeneous materials formulations[2].

\section{FABRICATION METHODS}

Fabrication of particulate and discontinuously reinforced Aluminium based metal matrix composites can be achieved by standard metallurgical processing methods like powder metallurgy, direct casting, rolling, forging and extrusion, and further the products can be shaped, machined and drilled by using conventional machining facilities. Composite materials are characterized by good mechanical properties over a wide range of temperature. The choice of the processing method depends on the property requirements, cost factor consideration and future applications prospects. Composite materials with a metal or an alloy matrix can be produced either by casting or by powder metallurgy methods are considered as potential material candidates for a wide variety of structural application in the transportation, automobile and sport goods manufacturing industries due to the superior range of mechanical properties they possess[3]. Conventional secondary fabrication methods can be used to produce a wide range of composite product forms, making them relatively inexpensive compared to other advanced composites reinforced with continuous filaments. Among these are 
increased strength, decreased weight, higher service temperature, improved wear resistance and higher elastic module. The main advantage of composites lies in the tailorability of their mechanical and physical properties to meet specific design criteria. During the production of metal matrix composites, several oxides have been used as reinforcements, in the form of particulates, fibers or as whiskers. For example, alumina, zirconium oxide and thorium oxide particulates are used as reinforcements in aluminium, magnesium and other metallic matrices. Very few researchers have reported on the use of quartz as a secondary phase reinforcement particulate in an aluminium or aluminium alloy matrix, due to its aggressive reactivity between these materials[4]. Preliminary studies showed that the contact between molten aluminium and silica-based ceramic particulates have destroyed completely the second phase microstructure, due to the reduction reaction which provokes the infiltration of liquid metal phase into the ceramic. Previous works carried out by using continuous silica fibres as reinforcement phases in aluminium matrix showed that even at temperatures nearer to 400 degree centigrade silica and aluminium can react and produce a transformed layer on the original fibre surface as a result of solid diffusion between the phases and due to the aluminium-silicon liquid phase formation. In the processing of metal matrix composite, one of the subjects of interest is to choose a suitable matrix and a reinforcement material. In some cases, chemical reactions that occur at the interface between the matrix and its reinforcement materials have been considered harmful to the final mechanical properties and are usually avoided. Sometimes, the interfacial reactions are intentionally induced, because, the new layer formed at the interface acts as a strong bond between the phases[5].

\section{EHNACEMENT OF MECHANCIAL PROPERTIES IN COMPOSITES}

Metal matrix composite materials are defined as materials whose microstructures compromise a continuous metallic matrix phase into which a second phase, or phases, have been artificially introduced. This is contrast to conventional alloys whose microstructures are produced during processing by naturally occurring phase transformations. Metal matrix composites are distinguished from the more extensively developed resin matrix composites by virtue of their metallic nature in terms of physical and mechanical properties and by their ability to lend themselves to conventional metallurgical processing operations. Electrical conductivity, thermal conductivity and non-inflammability, matrix shear strength, ductility and abrasion resistance, ability to be coated, joined, formed and heat treated are some of the properties that differentiate metal matrix composites from resin matrix composites. They are a class of advanced materials, which have been developed for weight-critical applications in the aerospace industry. reinforced composites can be made with properties that are isotropic in three dimensions or in a plane[6].

\section{THE ROLE OF METAL MATRIX COMPOSITES IN AEROSPACE AND AUTOMOTIVE INDUSTRIES}

During the last decade, because of their improved properties, MMCs are being used extensively for high performance applications such as in aircraft engines and more recently in the automotive industries. Aluminium oxide and silicon carbide powders in the form of fibers and particulates are commonly used as reinforcements in MMCs and the addition of these reinforcements to aluminum alloys has been the subject of a considerable amount of research work. Aluminium oxide and silicon carbide reinforced aluminum alloy matrix composites are applied in the automotive and aircraft industries as engine pistons and cylinder heads, where the tribological properties of these materials are considered important. Therefore, the development of aluminum matrix composites is receiving considerable emphasis in meeting the requirements of various industries[7].

\section{INDUSTRIAL APPLICATIONS OF METAL MATRIX COMPOSITES}

Graphite fibres reinforced in aluminium and magnesium matrices are applied in satellites, missiles and in helicopter structures. Lead matrix composites having graphite fibres are used to make storage-battery plates. Graphite fibres embedded in copper matrix are used to fabricate electrical contacts and bearings. Boron fibres in aluminium are used as compressor blades and structural supports. The same fibres in magnesium are used to make antenna structures. Titanium-boron fibre composites are used as jet-engine fan blades ${ }^{[8]}$. Molybdenum and tungsten fibres are dispersed in cobalt-base super alloy matrices to make high temperature engine components. Squeeze cast MMCs generally have much better reinforcement distribution than compo cast materials. This is because 
a ceramic preform is used contains the desired weight fraction of reinforcement rigidly attached to one another so that movement is inhibited[9]. Consequently, clumping and dendritic segregation are eliminated. Porosity is also minimized, since pressure is used to force the metal into interfiber channels, displacing the gases. Grain size and shape can vary throughout the

Table 1. Special features and applications of metal matrix composite materials

\begin{tabular}{|c|c|c|}
\hline $\begin{array}{l}\text { Metal matrix } \\
\text { composite type }\end{array}$ & $\begin{array}{l}\text { Industrial } \\
\text { Applications }\end{array}$ & Special Features \\
\hline $\begin{array}{l}\text { Graphite } \\
\text { reinforced in } \\
\text { aluminium }\end{array}$ & Bearings & $\begin{array}{l}\text { Cheaper, lighter, } \\
\text { self-lubricating, } \\
\text { conserves } \\
\text { Copper, lead, } \\
\text { tin, Zinc }\end{array}$ \\
\hline $\begin{array}{l}\text { Graphite } \\
\text { reinforced in } \\
\text { aluminium, } \\
\text { Silicon carbide } \\
\text { reinforced in } \\
\text { aluminium, } \\
\text { aluminium oxide } \\
\text { reinforced in } \\
\text { aluminium, }\end{array}$ & $\begin{array}{l}\text { Automobile } \\
\text { pistons, Cylinder } \\
\text { liners, Piston } \\
\text { rings, } \\
\text { Connecting rods }\end{array}$ & $\begin{array}{l}\text { Reduced wear, } \\
\text { anti seizing, cold } \\
\text { start, lighter, } \\
\text { conserves fuel, } \\
\text { Improved } \\
\text { efficiency. }\end{array}$ \\
\hline $\begin{array}{l}\text { Graphite } \\
\text { reinforced in } \\
\text { copper }\end{array}$ & $\begin{array}{l}\text { Sliding electrical } \\
\text { contacts }\end{array}$ & $\begin{array}{l}\text { Excellent } \\
\text { conductivity and } \\
\text { anti seizing } \\
\text { properties. }\end{array}$ \\
\hline $\begin{array}{l}\text { Silicon carbide } \\
\text { reinforced in } \\
\text { aluminium }\end{array}$ & $\begin{array}{l}\text { Turbocharger } \\
\text { impellers }\end{array}$ & $\begin{array}{l}\text { High temperature } \\
\text { use }\end{array}$ \\
\hline \multicolumn{2}{|c|}{$\begin{array}{l}\text { Glass or Carbon bubbles reinforced } \\
\text { in aluminium }\end{array}$} & $\begin{array}{l}\text { Ultra light } \\
\text { Material. }\end{array}$ \\
\hline $\begin{array}{l}\text { Cast Carbon } \\
\text { fibre reinforced } \\
\text { magnesium fibre } \\
\text { composites }\end{array}$ & $\begin{array}{l}\text { Tubular } \\
\text { composites for } \\
\text { space structures }\end{array}$ & $\begin{array}{l}\text { Zero thermal } \\
\text { expansion, high } \\
\text { temperature } \\
\text { strength, good } \\
\text { Specific strength } \\
\text { and Specific } \\
\text { stiffness. }\end{array}$ \\
\hline $\begin{array}{l}\text { Zircon reinforced } \\
\text { in } \\
\text { aluminium-silicon } \\
\text { alloy, aluminium } \\
\text { silicate } \\
\text { reinforced in } \\
\text { aluminium }\end{array}$ & $\begin{array}{l}\text { Cutting tool, } \\
\text { Machine } \\
\text { Shrouds, } \\
\text { Impellers }\end{array}$ & $\begin{array}{l}\text { Hard, Abrasion- } \\
\text { resistant } \\
\text { materials. }\end{array}$ \\
\hline
\end{tabular}

infiltrated preform because of heat flow patterns. Secondary phases typically form at the fibre-matrix interface, since the lower freezing solute-rich regions diffuse toward the fibre ahead of the solidifying matrix. In recent years, the aerospace, military and automotive industries have been promoting the technological development of composite materials to achieve good mechanical strength/density and stiffness/density ratio. Modern fiber-reinforced or particulate reinforced metal matrix composites are produced by casting techniques; find a wide variety of applications due to the low cost of fabrication and achievable engineering properties and shown in Table-1[10].

Some of the properties are high longitudinal and transverse strengths at normal and elevated temperatures, near-zero coefficients of thermal expansion, good electrical and thermal conductivities and excellent antifriction, anti abrasion, damping and machinability properties. The application of composite materials is well established in aircraft technology and they are now applied in fuselage-production technologies as well as in jet engine technologies. Application in car production technology is growing very fast, although it is still not as common as in aircraft technology[11]. Due to mechanical, electrical and heat resistant properties, their application in the electronics industries are also growing considerably. Composite material parts are applied in electronic sub-assemblies, lasers and computer parts can work at higher temperature and function with better efficiency when compared to conventional electronic materials.

Application of composites in the automotive, transportation and construction industries depends on the choice of cost affordable factor. Apart from the emerging and economical processing techniques that combine quality and ease of operations, researchers are at the same time turning to particulate-reinforced aluminium-metal matrix composites because of their relatively low cost and isotropic properties especially in those applications not requiring extreme loading or restricted thermal conditions in the case of automotive components. The presence of aluminium alloys as matrix materials are due to its comparative advantages, including low cost and ease of handling. The space shuttle uses boron reinforced aluminium tubes to support its fuselage frame, which decreases the mass of the space shuttle by more than $145 \mathrm{~kg}$. It has also reduced the thermal insulation requirements because 
of its lower thermal conductivity[12]. The mast of the Hubble telescope uses carbon-reinforced aluminium matrix composites. Precision components in the missile guidance systems demands dimensional stability and the geometries of the components cannot change during usage. Metal matrix composites such as silicon carbide reinforced aluminium composite satisfy this requirement since they have high micro-yield strength. In addition, the weight fraction of silicon carbide can be varied to have a coefficient of thermal expansion compatible with other parts of the system assembly. Metal matrix composites are now used in automotive engines, which are lighter than their metal component parts. In addition, metal matrix composites are the unique materials of choice for gas turbine engines due to their high strength and low weight. The range of metal matrix composite materials applications is very large. Some of the important metal matrix composite components are applied and used as insulation materials for electrical construction, supports for circuit breakers and printed circuits, armours, boxes and covers, antennas, radomes, tops of television covers, cable tracks, wind mills, housing cells, chimneys, concrete moulds, domes, windows, facade panels, partitions, doors, and furniture. Automotive engineering parts like automotive body parts, wheels, shields, radiator grills, transmission shafts, suspension springs, chassis, suspension arms, casings, highway tankers, isothermal trucks, trailers, wagons, doors, seats, interior panels, and ventilation housings. In marine transports, it is used to fabricate hovercrafts, rescue crafts, patrol boats, trawlers, landing gears, anti-mine ships, racing boats and canoes. In air transports, MMCs are used as passenger aircrafts, composite gliders, leading edges, ailerons, vertical stabilizers, helicopter blades, propellers, transmission shafts and aircraft brake discs. For space transports, it is used to make rocket boosters, reservoirs, nozzles and shields for atmosphere re-entrance. Some of the general mechanical applications are as gears, bearings, housing and casings, jack body, robot arms, fly wheels, weaving machine rods, pipes, components for drawing table, compressed gas bottles, tubes for offshore platforms, and pneumatics for radial frames. It is widely applied in sports and recreation industries to manufacture tennis and squash rackets, fishing poles, skis, poles used in jumping, sails, surfboards, roller skates, bows and arrows, javelins, protection helmets, bicycle frames, golf balls and golf sticks, and oars[13].

\section{CONCLUSIONS}

It is concluded that metal matrix composite materials are continuously displacing traditional engineering materials because of their advantages of high stiffness and strength over homogeneous materials formulations. These tailored advanced materials have high potential properties engineered for various industrial applications. Composite experts have carried out a detailed investigation on the strengthening mechanism of composites. They have found that the particle size and its weight fraction in metal matrix composites influences the generation of dislocations due to thermal mismatch and as well as the effect influenced by the developed residual and internal stresses. The researchers have predicted that the dislocation density is directly proportional to the weight fraction and due to the amount of thermal mismatch. Consequently, this effect would be significant for fine particles and for higher weight fractions.

\section{ACKNOWLEDGEMENT}

The author expresses his thanks and gratitude to the faculty of manufacturing engineering, Universiti Teknikal Malaysia Melaka.

\section{REFERENCES}

[1] Feest E.A., 1996, Metal Matrix Composites for Industrial Application, Materials \& Design; 7(2):58-64.

[2] Ivana K Patridge,. 1989, Advanced composites, Elsevier applied science, Elsevier Science Publishers Ltd, England, UK;

[3] Holt D. 1985; Materials Technology for Aerospace Applications. Materials \& Design 6(1): 18-24.

[4] Donald R Askeland. 1994; The science and engineering of materials. PWS Publishing Company, USA, Third edition;

[5] Almond E.A. ard Metals, 1986; Materials \& Design, 7(6): 324-329.

[6] Froes F.H. 1989; Aerospace Materials for the Twenty-First Century. Materials \& Design, (109)3: 110-120.

[7] Murray G.T. 1997; Handbook of materials selection for engineering applications. Marcel Dekker Inc, USA.

[8] Meetham G.W. 1989; The Future of Composites in Gas Turbine Engines. Materials \& Design 10(5): 231-234.

[9] Rizkalla H.L. and Abdulwahed A. 1996; Some mechanical properties of metal-nonmetal $\mathrm{Al}_{-} \mathrm{SiO}_{2}$ particulate composites. Journal of materials processing technology, 56: 398-403. 
[10] Polmear I.J. 1981; Light Alloys- Metallurgy of the light metals. Metallurgy and materials science series, Edward Arnold (publishers) Ltd, London, UK.

[11] Ivana K Patridge. 1989 Advanced composites. Elsevier applied science, Elsevier Science Publishers Ltd, England, UK.

[12] Thoguluva Raghavan Vijayaram: 2003-2006 Processing and properties studies of cast particulate reinforced aluminium $-11.8 \%$ silicon alloy based metal matrix composites, $\mathrm{PhD}$ Thesis in Mechanical Engineering, Faculty of Engineering, Universiti Putra Malaysia, UPM 43400 Serdang, Selangor Darul Ehsan, Malaysia

[13] Fridlyander J.N., 1995; Metal Matrix Composites, Soviet Advanced Composites Technology Series, Chapman \& Hall, London, UK.

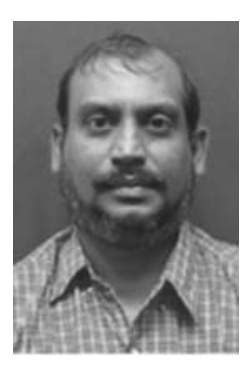

Dr. ThoguluvaRaghavanVijayaram is a Doctorate in Mechanical Engineering (Metal Matrix Composites), from Universiti Putra Malaysia. He has a wide range of work experience, in academic research and in the industry. His areas of expertise include Advanced Casting Technology and Techniques, Composite Materials and Processing, New Materials and Process Development. 